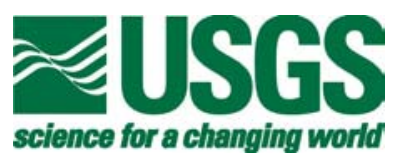

\title{
Specification Aggregate Quarry Expansion - A Case Study Demonstrating Sustainable Management of Natural Aggregate Resources
}

By

William H. Langer

U.S. Geological Survey

Denver, Colorado

M.L. Tucker

Lafarge North America Inc.

Denver, Colorado

This report is preliminary and has not been reviewed for conformity with U.S. Geological Survey editorial standards or with the North American Stratigraphic Code.

Any use of trade, firm, or product names is for descriptive purposes only and does not imply endorsement by the U.S. Government.

Open-File Report 03-121

U.S. Department of the Interior

U.S. Geological Survey 


\section{Abstract}

Many countries, provinces, territories, or states in the European Union, Australia, Canada, the United States, and elsewhere have begun implementing sustainability programs, but most of those programs stop short of sustainable management of aggregate resources. Sustainable practices do not always have to be conducted under the title of sustainability. This case study describes how Lafarge, a large multinational construction materials supplier, implemented the principles of sustainability even though there was an absence of existing local government policies or procedures addressing sustainable resource management.

Jefferson County, Colorado, USA, is one of three counties in the six-county Denver, Colorado, region that has potentially available sources of crushed stone. Crushed stone comprises 30 percent of the aggregate produced in the area and plays a major role in regional aggregate resource needs. Jefferson County is home to four of the five crushed stone operations in the Denver region. Lafarge operates one of those four quarries.

Lafarge recently proposed to expand its reserves by exchanging company-owned land for existing dedicated open space land adjacent to their quarry but owned by Jefferson County. A similar proposal submitted about 10 years earlier had been denied. Contrary to the earlier proposal, which was predicated on public relations, the new proposal was predicated on public trust. Although not explicitly managed under the moniker of sustainability, Lafarge used basic management principles that embody the tenets of sustainability.

To achieve the goals of sustainable aggregate management where no governmental policies existed, Lafarge not only assumed their role of being a responsible corporate and environmental member of the community, but also assumed the role of facilitator to encourage and enable other stakeholders to responsibly resolve legitimate concerns regarding the Lafarge quarry proposal. Lafarge successfully presented an enlightened proposal where the county will gain 745 acres of new open space land in exchange for 60 acres of current open space land adjacent to the quarry. The process involved collaborative efforts by all stakeholders and resulted in an outcome that balances the needs of society, the environment, and business.

\section{Introduction}

Natural aggregates - sand, gravel, and crushed stone - are granular materials composed of rock fragments that are mined or quarried and used in their natural state except for such operations as crushing, washing, and sizing. Natural aggregate is an essential commodity in modern society. Buildings, highways, roads, bridges, railroads, airports, seaports, water and waste treatment facilities, and energy generation facilities are all heavily dependent on natural aggregate. At every stage of life, nearly every individual in society uses products made with aggregate.

Crushed stone and sand and gravel together comprise the top non-energy mineral resource in both the world and in the United States. In the United States, about 2.74 billion tons of aggregate worth about $\$ 14.5$ billion was produced during 2000 (Tepordei, 2002; Bolen, 2002). Approximately 15 billion tons of aggregate worth about $\$ 76$ billion are annually produced throughout the world (Regueiro and others, 2002).

Natural aggregate can be produced from a broad variety of geologic environments, but even though potential sources of aggregate are widely distributed throughout the world, there are large regions where natural aggregate sources are non-existent (Langer, 1988). Furthermore, aggregate resources must meet certain physical and chemical quality parameters that are determined by the final application. Departures from any quality specifications can make potential aggregate unsuitable for some specific uses (Langer and Knepper, 1998).

An aggregate operation must consider all costs, including acquisition, operation, compliance with regulations, transportation to market, environmental management, and reclamation, in order to be profitable. These factors make opening a new operation a complicated process that can cost millions of dollars and take many years. Aggregate is a high-bulk, low unit value commodity that derives much of its value from being located near the market. Thus, it is said to have a high place value (Bates, 1969). Transporting aggregate long distances can add significantly to the overall price of the product (Leighton, 1991). For example, a city of 100,000 can expect to pay an additional $\$ 1.3$ million for each additional 10 miles that the aggregate it uses must be hauled (Ad Hoc Aggregate Committee, 1998). Therefore, aggregate operations frequently are located near population centers and other market areas.

Despite society's dependence on natural aggregate, urban expansion often works to the detriment of the production of those essential raw materials. "Resource sterilization" occurs when the development of a resource is precluded by another existing land use. For example, aggregate resources that exist under a housing development or shopping center commonly will not be extracted.

Before an aggregate resource can be developed, the extraction site must qualify for all necessary permits and 
the approving officials must be convinced that the operation can take place without adversely affecting the environment. Proposed aggregate operations have become the rallying point for citizens, and citizen involvement in the public hearing process has changed from participatory to absolute opposition (Bauer, 1991). Today, we are in a situation where it is extremely difficult to obtain necessary permits to initiate new aggregate operations.

A core issue surrounding the sustainable development of natural aggregate resources is the conflict between regional needs and local opposition to resource extraction. This conflict occurs because the negative impacts of extraction are located near the site of extraction, while the benefits from resource extraction are dispersed throughout an entire region. Dunn (1983) termed the conflict, and the consequences arising from it, the "Dispersed Benefit Riddle." The regional benefits commonly are not considered in the local permitting process (Dunn, 1983), and if resource extraction is denied because of local opposition, other costs arise, such as those associated with longer haul routes resulting in more traffic, more accidents, more fuel consumption, generation of more greenhouse gasses, greater wear and tear on vehicles, and higher vehicle replacement rates. Any gain by the local community that restricts extraction is usually at the expense of the greater public, the greater environment, and some other local area where extraction ultimately takes place.

Sterilization, permits, and regulations restrict development or expansion of aggregate production in established areas more than any actual limitations of suitable resource availability (Poulin and others, 1994). Bauer (1991) concluded that local units of government were unwilling or seem unprepared to deal objectively with the conflict between regional needs and local opposition, and the failure to plan for the protection and extraction of aggregate resources often results in increased consumer cost, environmental damage, and an adversarial relation between the aggregate industry and the community.

\section{History of Quarrying in the Denver, Colorado area}

The area around Denver, Colorado, USA (figure 1), obtains a significant amount of its aggregate resources from quarries that produce crushed stone. Of the six counties in the Denver area, only three - Boulder, Douglas, and Jefferson - have any source of bedrock suitable for use as crushed stone; Adams, Arapahoe, and Denver Counties have no crushed stone resources (figure 2).

Crushed stone has been produced in the Denver area since the early $20^{\text {th }}$ century (Schowchow, 1980). Four

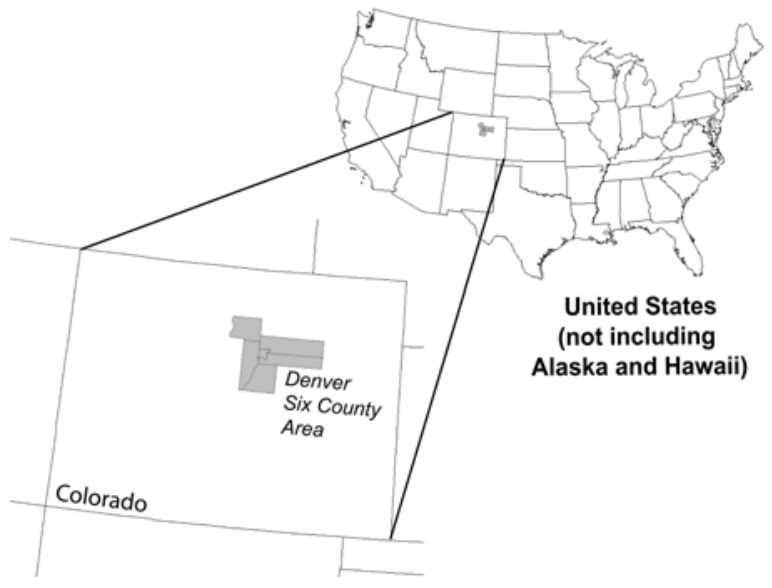

Figure 1 - Index map showing the six counties in the Denver area, Colorado, USA.

quarries produced crushed stone at South Table Mountain, in Jefferson County, Colorado, with the first operation starting as early as 1905 . These operations worked intermittently until the 1950's, and provided concrete and asphalt aggregates. One of these four quarries, the Wunderlich quarry, provided rip-rap for Cherry Creek Dam, in Denver. The Rogers Brothers quarry, started in 1925 and enlarged in 1949, mined crushed stone from North Table Mountain in Jefferson County and provided concrete aggregates for Harlan County Dam near McCook, Nebraska (Argall, 1949). The Bertrand quarry, operating at the mouth of Clear Creek Canyon in Golden, started in 1926, but closed in 1975 because of a threatening landslide. Many years ago, two crushed stone quarries operated north of Golden at Ralston Reservoir.

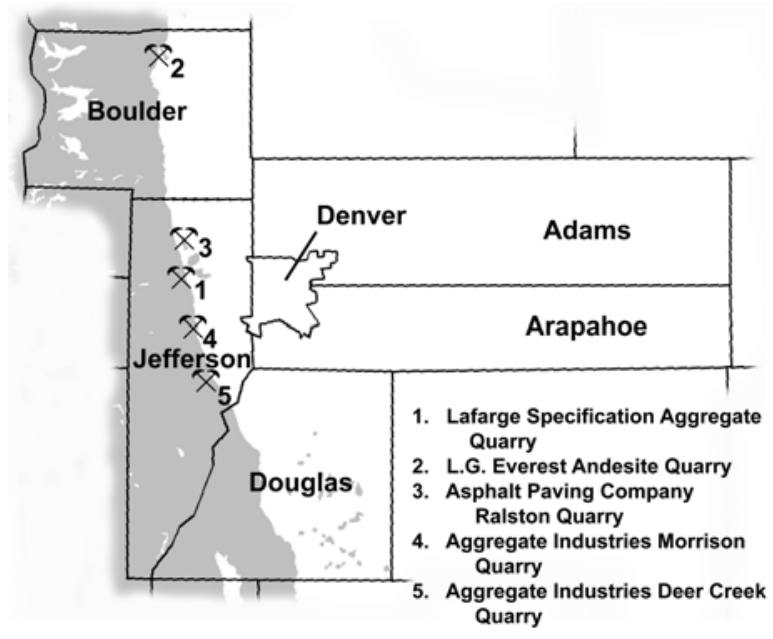

Figure 2 - Index map showing the six counties in the Denver area, areas of bedrock (shaded gray), and locations of operating crushed stone quarries. 
Five crushed stone quarries, all started operations prior to 1976 , operate in the Denver area counties today (figure 2). The Holloway quarry on Jackson Gulch south of Golden started in 1965 and originally produced rip-rap for Chatfield Dam near Littleton, Colorado, and aggregates for the construction of nearby Interstate 70 . Lafarge now owns that quarry, which is called the Specifications Aggregate Quarry, and is the primary subject of this discussion. Two other quarries, now operated by Aggregate Industries, are the Deer Creek Canyon Quarry, started in 1970 in Deer Creek Canyon west of Chatfield Reservoir, and the Strain Gulch (Morrison) Quarry that started in 1971 south of Morrison, Colorado. The Asphalt Paving Company operates the Ralston Quarry north of Golden at Ralston Reservoir, which was first permitted in 1975. L.G. Everist operates the Andesite Quarry located southwest of Lyons, Colorado. Other quarries in the area provide limestone for use in the manufacture of cement or dimension stone for building and decorative use, but do not produce crushed stone for use as aggregate.

The production of crushed stone has increased greatly from the 1960 's, and crushed stone will become an increasingly important source of aggregate in the Denver market. Statewide, starting in the late 1950's, crushed stone has become a significant component of the total aggregate production stream (figure 3). Crushed stone production in the Denver area has increased from just three percent of the State total in the 1960's to 56 percent in the 1990's. During 1960, 99 percent of the aggregates in the Denver area were derived from sand and gravel sources. In contrast, during 1997, only 55 percent of the aggregates demand in the Denver area was being met from sand and gravel sources while 31 percent was being met from crushed stone. The remaining 14 percent of the aggregate was derived from recycled concrete or asphalt (Wilburn and Langer, 2000).

Today, crushed stone serves an important function in the Denver area beyond just being a replacement for sand and gravel. For example, specifications for aggregates used in concrete for the runways at Denver International Airport required crushed stone. Similarly, asphalt highways typically require crushed stone aggregates in order to achieve the required strength parameters. Highways being constructed with money from the Federal government commonly must meet SUPERPAVE specifications, which in effect require the use of sand manufactured from the crushing of rock and prohibit the use of natural sand. It is clear that crushed stone plays a key role in the sustainable management of aggregate resources in the Denver area.

Many of the potential aggregate resources in the Denver area are not accessible for extraction. The population centers have built out and gradually encroached upon existing deposits, both sand and gravel and crushed stone resources, thus rendering some nearby

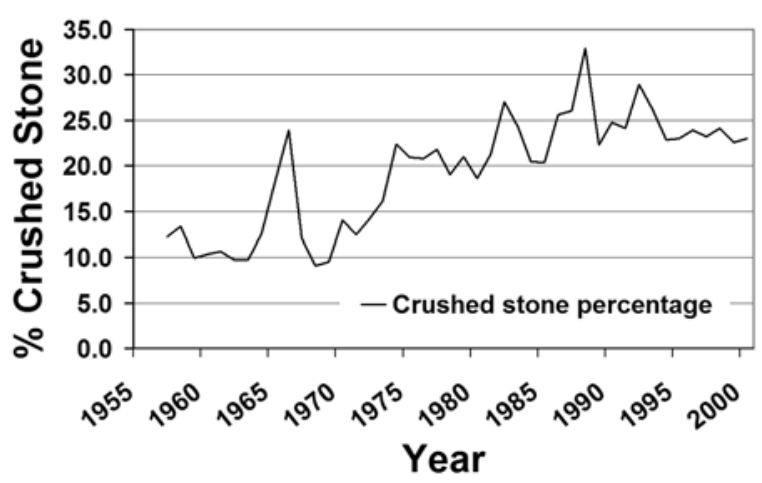

Figure 3 - Graph showing percentage of natural aggregate production in Colorado, USA that is crushed stone.

resources inaccessible. Sheridan (1967) predicted that restrictive zoning, lack of general public understanding of sand and gravel occurrence and mining operations, and conflicting land uses would cause a shortage of nearby, low-cost aggregates in Denver. James Cooley (1971) restated the problem at the $74^{\text {th }}$ National Western Mining Conference.

During 1973, the Colorado legislature officially recognized the problem and passed House Bill 1529. The act declared that: 1) the State's commercial mineral deposits were essential to the State's economy, 2) the populous counties of the State faced a critical shortage of such deposits, and 3) such deposits should be extracted according to a rational plan that was calculated to avoid waste and would cause the least practical disruption to the ecology and quality of life of the citizens.

By 1974, commercial deposits of significant economic or strategic value to the area were mapped throughout the ten populous counties on the eastern slope of the Colorado Front Range, including the six Denver area counties (Schwochow and others, 1974a, 1974b). The mapping efforts focused on sand and gravel deposits; potential sources of crushed stone were only generally described and located.

Although counties were required to complete master plans by July 1, 1975, only two counties, neither in the Denver area, met the deadline. Lack of state funding, personnel shortages, and no provision for penalties were reasons given for delays (Stearn, 1979). Unfortunately, H.B. 1529 did not succeed at protecting existing aggregate resources in the Denver area. The U.S. Department of Labor (1981) pointed out that resource availability in the Front Range had continued to decline. They blamed the decline on adverse zoning, noncompliance with H.B. 1529, increased production, inadequate grain size to meet specifications, environmental concerns, and some notoriously poor operational procedures employed by some aggregate operators. 
In 1976, the Jefferson County planning department solicited a task force to prepare an outline and a master plan to manage aggregate resources. The resulting Mineral Extraction Policy Plan (Jefferson County, Colorado, 1977) has 17 goals, each of which has numerous associated policies. Those goals and policies overwhelmingly are designed to control the impacts of aggregate mining. Essentially the plan has no provisions to protect aggregate resources from encroaching land uses.

In 1986, the Jefferson County Commissioners convened a Roundtable, giving roundtable members the charge to formulate recommendations to guide decision making in the county regarding rezoning and the mining of aggregate. The Aggregate Resources Roundtable Report (Aggregate Resources Mining Roundtable, 1987) includes a variety of recommendations, including identification of preferred areas of extraction, public involvement, monitoring and enforcement, and mitigation of impacts. One recommendation deserves special mention, the recommendation to conduct informal meetings between the applicant and the citizenry and the appointment of an ombudsperson to facilitate those meetings. The purpose of the meetings is to gain citizen input before the final plans are developed, and the Roundtable report suggests the time between the informal meeting and formal hearing could be as much as 90 days.

In spite of the Mineral Extraction Policy Plan and the Aggregate Resources Roundtable report, the efforts to permit the extraction of aggregate resources remains a contentious issue in Jefferson County. Shortly after the passage of H.B. 1529, five companies submitted applications to open new quarries or reactivate older sites in Jefferson and Boulder Counties. During 1980-1981, all five of the applications were denied (Schwochow, 1981). Although additional new applications to open new crushed stone quarries have been submitted, none has been approved in Jefferson or Boulder Counties since the passage of H.B. 1529, and applications have been denied as recently as 1999 .

\section{Sustainable Management of Aggregate Resources}

The term sustainability dates back to the 1980 World Conservation Strategy, and was given prominence in Our Common Future, otherwise known as the "Bruntland Commission Report". That report states the purpose of sustainable development is to ensure that development "meets the needs of the present without compromising the ability of future generations to meet their own needs" (World Commission on Environment and Development, 1987, p. 43). At a minimum, sustainable development must not endanger the natural systems that support life on earth: the atmosphere, the waters, the soils, and the living creatures including people.

In the simplest sense, the "manufactured capital" and "natural capital" (natural resources) that one generation passes on to the next must be maintained or enhanced in order to achieve sustainable development. This philosophy gets somewhat confusing when dealing with a non-renewable resource such as natural aggregate, in contrast to a renewable resource such as forestry products. Aggregate resources, like all non-renewable resources, are indeed finite. However, on a worldwide scale, the potential supply of aggregate resources is so large that "finite" has no practical meaning.

Consequently - on a world scale - there is no real concern about running out of aggregate resources and sustainability does not need to be invoked to ensure adequate supplies of aggregate. But natural aggregate of suitable quality for an intended use can be in short or non-existent supply on a regional or local scale. In the realm of sustainability, having an accessible local supply of aggregate resources takes on great significance because transporting aggregate long distances not only adds to the overall cost of the product, but also adds to the overall cost to the environment as described above in the "Dispersed Benefit Riddle" (Dunn, 1983).

Sustainable practices do not always have to be conducted under the title of sustainability. Many countries, provinces, territories, or states in the European Union, Australia, Canada, the United States and elsewhere are beginning to develop sustainability programs, however, these efforts generally stop short of including aggregate resources (Langer and others, in press). In spite of the lack of government policy promoting sustainability, some aggregate companies in the United States and elsewhere have already begun implementing some of the concepts of sustainability without waiting for government intervention.

There is a variety of key policies and issues that relate to the sustainable management of aggregate resources (see for example Department of the Environment, Transport, and the Regions, 2000). These policies are applicable for governmental agencies, but have little direct application to the aggregate industry. There is little or no clear guidance to the aggregate industry regarding application of sustainable management principles. Therefore, the industry must design their own sustainable practices by interpreting and drawing from basic sustainability tenets.

The practical application of sustainability of aggregate resources requires that each of the primary stakeholders - government, industry, public, and other non-governmental organizations - assume certain responsibilities (Langer and others, 2003). The government is responsible for developing policies that provide the conditions for success. The industry must work to be recognized as a responsible corporate and 
environmental member of the community. The public and non-governmental organizations must become informed about aggregate resource management issues and constructively address both their own and a wide range of objectives and interests. All stakeholders - the government, industry, and the public - have the responsibility resolve legitimate concerns regarding sustainable aggregate extraction.

By working within these broad guidelines, the industry can effectively manage its resources and reserves in a sustainable manner. The company is clearly required to assume a role as a responsible corporate and environmental member of the community. But if sustainable management policies are not in place, the company must also assume the role of the facilitator who both brings the various stakeholders together and encourages each of the stakeholder groups to assume their proper roles.

\section{Specification Aggregate Quarry Expansion}

Quarries have operated in Jefferson County, Colorado for many years, but since the early 1980's, new quarry applications have raised serious logistical, environmental, and social concerns. No applications for new quarries have been approved since 1976. For example, a recent attempt to rezone property so that aggregate extraction could take place was unanimously denied in 1999 after almost 17 months of community effort to oppose the proposal.

Lafarge, or its predecessors, have been operating their largest quarry in the Denver area, the Specification Aggregate Quarry, since 1965. The 222 acre quarry is located just west of the metropolitan area and is bordered on the west by Mother Cabrini Shrine, on the North by a small retail and amusement park, on the East by a state road, and on the south by Matthews/Winter Park - land acquired by Jefferson County for use as open space (figure 4).

The quarry is within the City of Golden, Colorado, and operates pursuant to a mine plan approved by the Colorado Mined Land Reclamation Board and according to a Planned Unit Development (PUD) originally approved by the City of Golden in 1977 .

Lafarge tendered a proposal that would adjust the southern boundary of its quarry to include 60 acres of land contained in the Matthews/Winter Park. Lafarge proposed to compensate the county by transferring to the county three other parcels of land adjacent to the quarry totaling 60 acres, plus additional land owned by the company elsewhere in the county. A major challenge of this proposal was the fact that the 60 -acre parcel in the Matthews/Winter Park had been acquired by the Jefferson County Open Space Program and was owned

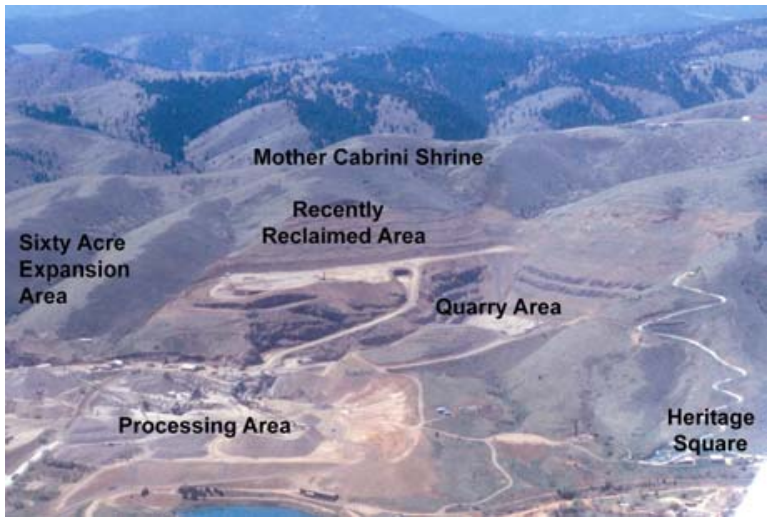

Figure 4 - Aerial photograph of the Lafarge Specification Aggregates Quarry, looking southwest.

by the County. The proposal represents a complicated open space transaction with wide ranging political, environmental, and philosophical implications.

Local environmental activists, many of whom were involved in starting the Open Space Program over 30 years ago in 1972, continue to monitor this program. The program is funded by a 0.5 percent sales tax, which currently generates over $\$ 40$ million per year, all specifically dedicated for open space purposes. The Jefferson County Open Space Program is considered by many to be the premier open space program in the United States, and many other open space programs have been modeled after it.

To provide an historical perspective, in 1992, the company that previously owned the quarry made a similar proposal to trade 400 acres of property on North Table Mountain (located approximately 5 miles north of the quarry) for 100 acres of open space located immediately adjacent to the quarry. This proposal was defeated by a majority vote of the Open Space Advisory Committee, the committee charged with making recommendations to the County Commissioners on all open space matters.

The proposal failed for several reasons, including the undesirable precedent of relinquishing open space for a commercial operation. In addition, the previous quarry operator had hired a well respected outside public relations firm with a great reputation to take the lead in interfacing with the elected officials and the community. Lafarge determined that the core problem leading to failure of the proposal was the lack of direct company outreach to the community and the perceived indifference of the company to issues raised regarding the quarry expansion. It was further determined that the community, including the elected officials, wanted to see a commitment by the company directly through its employees - not through an outside consultant who typically disappears once a project is completed. 
This realization embraces one of the basic tenets of sustainability: the industry must work to be recognized as a responsible corporate and environmental member of the community. Top management at Lafarge supported this kind of effort to be recognized and, consequently, took a very different approach in their land exchange proposal. The new proposal was to be built on public trust, not public relations.

Employees chosen for this very important responsibility were those who were willing to work in the local community for a number of years. Building and maintaining grassroots support was "kick started" by an employee who already was connected in the community. The key employee responsible for building and maintaining the grassroots connections (M.L. Tucker, coauthor of this paper) was a person who had been very involved in the community for a number of years - even before starting work with Lafarge over eight years ago. She had served on various committees appointed by the elected officials, including those dealing with land use, and had worked her way up to leadership positions in business organizations, ultimately to the Chairman of both the Chamber of Commerce and the local Economic Council. Each of these positions offered additional opportunities to interface regularly with both elected officials and key business and community leaders, resulting in the establishment and maintenance of strong community relationships. In addition, through these relationships, she was able to help establish contacts between the members of the Lafarge team and the people with whom they needed to interface on the project, and to coach them in developing relationships.

Relationship building has commonly not been a priority of the aggregate industry in the past. Historically, in this business, once ownership of the land or a lease of the mineral rights was secured, you were ready to remove rock. In today's world, you not only need to acquire those rights, you also need to secure the permission of your neighbors to operate - you need a social license to mine. Permission is secured by earning the trust of the neighbors and community. The way trust is earned is by building and maintaining relationships. Meaningful involvement in the community is key.

Equally important, this close interaction with the community allowed the company to understand how its proposal fit into the larger community plan. This is a second basic tenet of sustainability - that resource development must address the needs of the community, as well as the needs of the company. Consequently, the new proposal is significantly different from the 1992 proposal and offers compensating, long-term advantages to the community.

Under this innovative new proposal, the boundary of the quarry was adjusted by acquiring 60 acres of open space to the south (figure 5). In return, those 60 acres were replaced with the following:
- one prime commercial real estate parcel, consisting of approximately 20 acres;

- one 30 acre parcel, currently zoned for 212 residential dwelling units; and

- one 10 acre parcel of pristine, highly visible mountain property.

In addition, upon obtaining annexation and all necessary permits and zoning Lafarge will donate all of its land holdings on top of North Table Mountain (approximately 463 acres) to Jefferson County for use as Open Space land (figure 6).

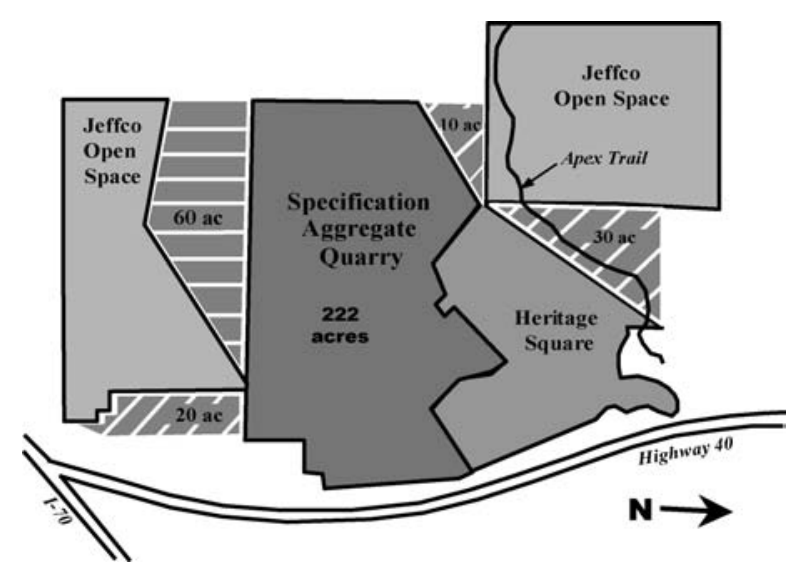

Figure 5 - Map of land parcel near the Specification Aggregate Quarry that Lafarge will transfer to Jefferson County (shown by diagonal pattern) in exchange for the land the County will transfer to Lafarge (shown by horizontal pattern).

During the negotiations the County asked if Lafarge would transfer the quarry land (222 acres) to the County upon completion of mining. When Lafarge agreed to do so, the County responded that they were not ready to make the decision to accept the quarry at this point in time. Lafarge gave the County an option to acquire the quarry land so that the County could make the decision at a later point in time.

This process was a true application of the mutual gains theory, which seeks to create a "win win" situation for the community, the governmental entities, and the company involved in the project. As a direct result of this project, the citizens of Jefferson County will gain as much as 745 acres of new open space. Preservation of the three parcels of land surrounding the quarry that were under threat of development and the acquisition and preservation of trailhead access to open space is a worthy outcome. The donation of land on North Table Mountain, which has been on the community's priority list for over 30 years, will substantially complete preservation of that mesa as open space. 
Lafarge is given ownership of the 60 acres and the right to remove rock for natural aggregate. In doing so, Lafarge has secured land that extends the life of the quarry by 20 years and secures a location for a ready mix plant and an existing asphalt plant. Securing additional reserves at this location, which is excellent from both its proximity to market and to the interstate highway, exhibits good business planning for all three product lines - aggregate, asphalt, and concrete. Lafarge has eliminated the need for another site at a "greenfield" (undeveloped) location and can utilize existing facilities such as plants, crushers, scale house, roads, and other infrastructure.

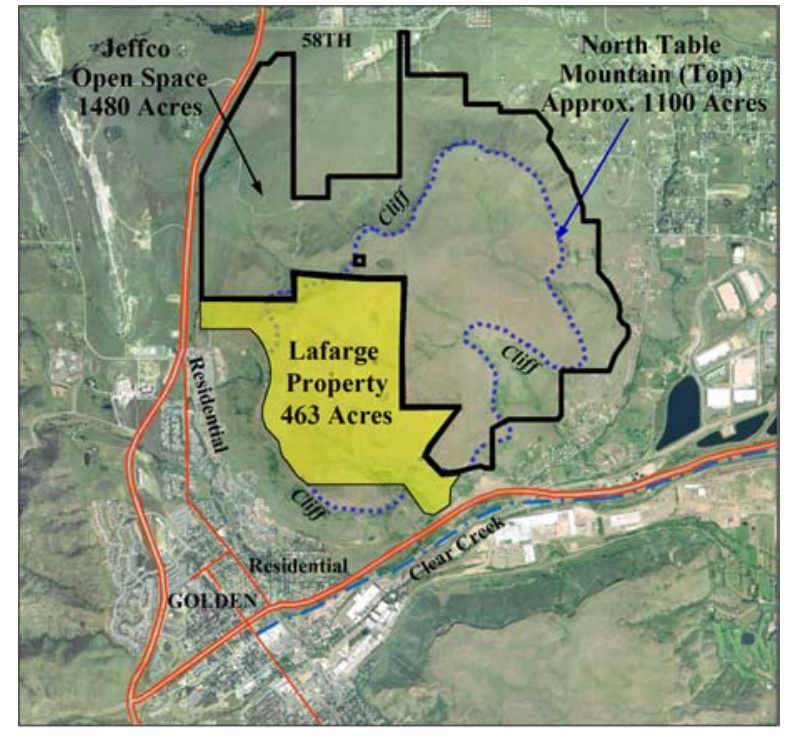

Figure 6 - Lafarge property on North Table Mountain.

A third key tenet of sustainable development is that all stakeholders should be able to participate in the decision process (Shields and others, 2002). Lafarge recognized that participation meant more than including stakeholders in the public hearing process. Therefore, Lafarge informally "floated" their proposal to local governmental, citizens, quasi-governmental, and environmental groups during the Fall of 2000. They listened to stakeholder input, assessed their concerns, and modified the proposal. It was not until about one and one half years later, February 2002, that they made formal presentations to citizens groups, the Jefferson County Open Space Committee, Jefferson County, and the City of Golden.

Even with this public involvement, the environmental watchdog group that started the Open Space Program was concerned that if this proposal was approved, the land trade would set a dangerous precedent, would discourage future donations of land to the Open Space Program, and would violate the policies and procedures that open space land shall not be disposed of if it is still serving its original purpose. Just prior to Lafarge making its formal proposal to expand the quarry, the watchdog group proposed changes to the open space policies and procedures that added several new requirements regarding disposal of open space land. One of the requirements increased the vote needed to support a disposition from a majority vote to essentially a unanimous vote of the Committee members.

During December 2002, a public hearing was held in Jefferson County to determine if the county would approve the proposed land exchange. Present in the room for this hearing were the County Commissioners and their staff and the applicant and his staff. In addition, there was a State Senator, a previous County Commissioner (from a political party other than the current commissioners), government officials from the City of Golden, a Sister from Mother Cabrini Shrine, the founder of the Jefferson County Open Space Program, the Chair of the Jefferson County Open Space Advisory Committee, the Chair of the Jefferson County Economic Council, the Chair of the Table Mesa Conservation Fund, the President of Save the Mesas, and a number of citizens who described themselves as avid hikers or neighbors of the quarry. All of the people not directly employed by the aggregate company had come to this hearing united in their opinion of the land exchange, and every single one of them spoke out in support of the land exchange. Comments such as "a balance between mineral extraction and open space," "county staff, Lafarge, and citizen groups should be congratulated," and "a great example of merging of environmental interests with business needs" typify the testimony. There was not a single dissenting opinion.

This proposal obtained approval of the County Commissioners as a direct result of an innovative combination of building public trust at the grassroots level, mutual gains approach, and continuous work to involve all stakeholders - three components of sustainable management. The proof of success was in three unanimous votes in favor of the expansion proposal by the independent County Commissioners with jurisdiction over the plan.

Historically, aggregate companies have taken the position that once the fact gathering required for the presentation of a project has been completed and the calculations of reserves, yields, and so forth have been made, the application should be formally submitted for approval (figure 7 - "reactive" timeline): legally and factually the application is ready for submission. However, at the time the application becomes formal, the project becomes subject to scrutiny, review, and comment - all in the public arena and in the media. Typically, this results in public criticism, and decisions often are based upon emotions and perceptions as opposed to being based upon fact. 
Although a company may be technically prepared to formally submit a proposal to the governmental officials, building grassroots support for the proposal prior to formal submission by meeting with the elected officials, community and business leaders, and the citizenry to inform them and solicit input is often advisable (figure 7 - "proactive" timeline). This time line often results in positive coverage by the media because the community is informed and in support of the proposal long before the formal submittal, and may even generate additional supportive testimony and letters in support of the proposal - a much more friendly way to achieve community and governmental support.

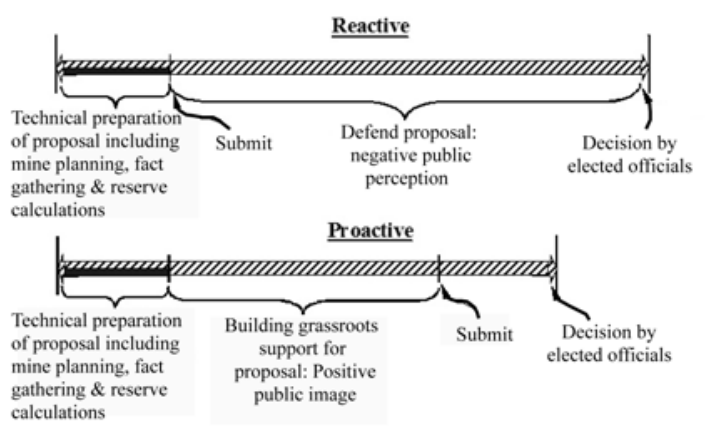

Figure 7 - Timeline typically chosen for this type of project in contrast with timeline for this case study.

\section{Conclusions}

National, regional, and local governments are implementing the practice of sustainable management of aggregate resources in only a few parts of the World, and there are few or no guidelines for the industry to follow. Nevertheless, the aggregate industry can independently utilize sustainable management techniques to achieve the goals of meeting their needs for reserves without compromising the ability of future generations to meet their needs.

Lafarge, a major aggregate producer in the area near Denver, Colorado, USA, submitted a proposal to enlarge their quarry holdings through an exchange of land owned by the company for dedicated open space land owned by Jefferson County, Colorado. A similar proposal submitted about 10 years earlier had been denied, and the new proposal represented a complicated open space transaction with wide ranging political, environmental, and philosophical implications.

During the application process, Lafarge employed three key tenets of sustainable management that relate to the aggregate industry: 1) industry must be a responsible corporate members of the community, 2) resource development must meet the needs of both the company and the community, and 3) all stakeholders must have the opportunity to participate in the process. A number of operational concepts necessary for the sustainable management of aggregate resources grew from these tenets. They are:

1. Establish community relationships - It is never too early for a company to get involved in the community in which they either do business, want to do business, or hope to stay in business. In today's world, it is through the permission of neighbors that aggregate companies are able to continue doing business. Company strategies for each of their principal markets need to include continued community involvement by key employees. Those key employees also need to assist other employees in developing and maintaining long-term community relationships.

2. Obtain executive support - The company president, his or her management team, and other appropriate managers must support the proposal. Develop a plan with input from both operations and management. Schedule team meetings regularly so that team members can exchange information and keep each other up to date.

3. Create benefits for the community - Understand how your proposal fits into the larger community plan and offer the community compensating, longterm advantages.

4. Communicate the plan - Identify the tools you will use to communicate the plan, such as videos, computer presentations, pamphlets, and field trips to the site. Make sure that your message to the various community groups, elected officials, and business leaders is consistent. Present the proposal to the elected officials well in advance of the formal presentation so that they are informed and stay informed as the proposal becomes more "public." Identify the real decision makers; sometimes they are different from the obvious ones. Know who influences the decision makers and why they have the influence.

5. Solicit feedback on the plan - Listen actively, take notes, ask questions, and show true interest in the communication. Make every effort to work in harmony with those of opposite views. Try to view the proposal through their eyes and analyze and address their issues and concerns before the final hearing.

6. Be visible and accessible - Be available beyond just normal business hours, Monday through Friday. Maintaining availability requires commitment of team members' personal time outside normal business hours, on a regular basis, over the term of this proposal.

7. Maintain your public trust - Remain active in the community after the proposal is approved and operations begin. 
The proposal was unanimously approved by the three independent County Commissioners responsible for land use decisions in Jefferson County. The authors are not aware of any other case in the United States, or in the world, where an expansion of a quarry onto pristine, dedicated open space land has been allowed.

As a direct result of this project, the citizens of Jefferson County will gain an additional 745 acres of open space including three parcels of land surrounding the quarry that were under threat of development and highly prized land on North Table Mountain, which has been on the community's open space priority list for over 30 years. The County also has the option to acquire the quarry land once quarrying is completed.

Lafarge is given ownership of 60 acres of previously dedicated open space land adjacent to the quarry and the right to remove rock for natural aggregate from that land. In doing so, Lafarge has secured land that doubles the life of the quarry and secures a location for a ready mix plant and an asphalt plant. In addition, Lafarge has eliminated the need to start a new quarry at a "greenfield" (undeveloped) location and can utilize existing facilities, such as plants, crushers, scale house, roads, and other infrastructure.

The fact that this proposal passed with no objections is testament to the planning and efforts that went into the project. The process employed by Lafarge truly embodies the spirit of sustainable management. The outcome was driven, not only by Lafarge, but also by the local government, special interest groups, and the citizens. The result is clearly a "win win" situation for the community, the governmental entities, and Lafarge.

\section{References}

Ad Hoc Aggregate Committee, 1998, Minnesota's aggregate resources - Road to the $21^{\text {st }}$ century: Ad Hoc Aggregate Committee for the Aggregate Resources Task Force, St. Paul, Minn., 34 p., Accessed on 12 March 2003 at http://www.commissions.leg.state.mn.us/aggregate.res ources/

Aggregate Resources Mining Roundtable, 1987, Report of the Aggregate Resources Mining Roundtable: Planning Department, Jefferson County, Colorado, 85 p.

Argall, G.O., Jr., 1949, Industrial minerals of Colorado: Quarterly of the Colorado School of Mines, v. 44, no. 2, $440 \mathrm{p}$.

Bates, R.L., 1969, Geology of the industrial rocks and minerals: New York, Dover Publications, Inc., 459 p.

Bauer, A.M., 1991, Mineral resource management programs and the construction aggregate industry: Planning and Zoning News, April, 1991, Planning and Zoning Center, Inc., Lansing, Mich., p. 5-7.
Bolen, W.P., 2000, Sand and gravel, construction: U.S. Geological Survey Minerals Yearbook, p. 66.1 - 66.4, 16 tables.

Cooley, J.B., 1971, Our rapidly disappearing sand and gravel deposits: 74th National Western Mining Conference and Exhibition, Mining Yearbook 1971, Colorado Mining Association, p. 17-20.

Department of the Environment, Transport, and the Regions, 2000, Planning for the supply of aggregates in England: Department of the Environment, Transport, and the Regions, Minerals and Waste Planning Division, Draft Consultation Paper, 70 p.

Dunn, J.R., 1983, Dispersed benefit riddle, in, Ault, C.R., and Woodard, G.S., eds., Proceedings of the 18th Forum on Geology of Industrial Minerals: Indiana Geological Survey Occasional Paper 37, p. 1-9.

Jefferson County, Colorado, 1977, Mineral extraction policy plan: Jefferson County, Colorado, $28 \mathrm{p}$.

Langer, W.H., 1988, Natural aggregates of the conterminous United States: U.S. Geological Survey Bulletin 1594, 33 p., 2 plates, scale 1:5,000,000.

Langer, W.H., and Knepper, D.H., Jr., 1998, Geologic characterization of natural aggregate, in Bobrowsky, P.T. (ed.), Aggregate resources - A global perspective: A.A. Balkema, Rotterdam, Netherlands, p. 275-293.

Langer, W.H., Giusti, C., and Barelli, G., 2003, Sustainable development of natural aggregate with examples from Modena Province, Italy: Society for Mining, Metallurgy, and Exploration Preprint 03-45, Littleton, Colorado, 9 p.

Langer, W.H., Šolar, S.V., Shields, D.J., and Giusti, C., in press, Sustainability indicators for aggregates, in Proceedings, Sustainable Development Indicators in the Minerals Industries, May 21-23, 2003, Milos, Greece.

Leighton, M.W., 1991, Industrial minerals resource identification and evaluation, in Bush, A.L., and Hayes, T.S., eds., Industrial Minerals of the Midcontinent - Proceedings of the Midcontinent Industrial Minerals Workshop: U.S. Geological Survey Bulletin 2111, p. 9-20.

Poulin, R., Pakalnis, R.C., and Sinding, K., 1994, Aggregate resources - Production and environmental constraints: Environmental Geology, v. 23, p. 221227.

Regueiro, M., Martins, L., Feraud, J., and Arvidsson, S., 2002, Aggregate extraction in Europe: The role of the geological surveys, in Geological Survey of North Rhine-Westphalia, ed., Raw materials planning in Europe - Change of conditions! New perspectives?: Proceedings, Third European Conference on Mineral Planning, Krefeld, Germany, October 8-10, p. 187198.

Schwochow, S.D., 1980, The effects of mineral conservation legislation on Colorado's aggregate industry, in Proceedings of the Fifteenth Forum on 
Geology of Industrial Minerals: Colorado Geological Survey Resource Series no. 8, p. 30-39.

, 1981, New quarries for Denver get "no" votes: Rock Products, v. 84, no. 9, p. 38-40, 72, 76.

Schwochow, S.D., Shroba, R.R., and Wicklein, P.C., 1974a, Sand, gravel, and quarry aggregate resources Colorado Front Range counties: Colorado Geological Survey Special Publication 5-A, 43 p.

, 1974b Atlas of sand, gravel, and quarry aggregate resources - Colorado Front Range counties: Colorado Geological Survey Special Publication 5-B, not paginated.

Sheridan, M.J., 1967, Urbanization and its impact on the mineral aggregate industry in the Denver, Colo., area: U.S. Bureau of Mines Information Circular 8320, 53 p.

Shields, D.J., Šolar S.V. , and Martin, W.E., 2002, The role of values and objectives in communicating indicators of sustainability: Ecological Indicators, v. 2 (1-2), p. 149-160.

Stearn, E.W., 1979, Master plans for minerals take effect: Rock Products, v. 82, no. 9, pp. 86-88.

Tepordei, V.V., 2000, Stone, crushed: U.S. Geological Survey Minerals Yearbook, p. 73.1 - 73.6, 26 tables.

U.S. Department of Labor, 1981, Report to the Denver Construction Committee on sand and gravel operations at Chatfield Dam and Recreation Area: U.S. Department of Labor, Office of Construction Industry Services, 4 p. and exhibits A-I.

Wilburn, D.R., and Langer, W.H., 2000, Preliminary report on aggregate use and permitting along the Colorado Front Range: U.S. Geological Survey OpenFile Report 00-258, 22 p.

World Commission on Environment and Development, 1987, Our common future: The World Commission on Environment and Development, Oxford University Press, Oxford, $400 \mathrm{p}$. 